\title{
HIV/AIDS and Construction Workers: Knowledge, Risk Sexual Behaviours and Attitude
}

\author{
Geraldine J. Kikwasi ${ }^{1} \&$ Sophia R. Lukwale ${ }^{2}$ \\ ${ }^{1}$ School of Architecture, Construction Economics and Management, Ardhi University, Dar es Salaam, Tanzania \\ ${ }^{2}$ Library Services, Ardhi University, Dar es Salaam, Tanzania \\ Correspondence: Geraldine J. Kikwasi, School of Architecture, Construction Economics and Management, Ardhi \\ University. P.O. Box35176, Dar es Salaam, Tanzania. Tel: 255-22-277-5004. E-mail: gkikwasi@yahoo.com
}

Received: October 11, $2017 \quad$ Accepted: November 3, $2017 \quad$ Online Published: November 20, 2017
doi:10.5539/gjhs.v10n1p37
URL: https://doi.org/10.5539/gjhs.v10n1p37

\begin{abstract}
Introduction: The construction industry depends mainly on labour to translate other resources into a physical object (i.e. building, road, airport etc.). The industry's workforce is always mobile and its activities are characterized by difficult working conditions. The mobile workforce of industry and their vulnerability to HIV/AIDS pandemic have been fairly researched. The objective of the study is to determine construction workers' HIV/AIDS knowledge, risk sexual behaviours and their attitude towards HIV/AIDS.
\end{abstract}

Method: The study adopted a cross sectional research design and purposive sampling method was used to select respondents. The researched area included sites in Dar es Salaam, Morogoro and Dodoma cities. A sample size involved 20 construction sites and 5 respondents from each site. A hundred questionnaires were distributed out of which 58 were fairly filled.The study adapted standard questionnaires developed by UNAIDS, Family Health International (FHI) and Demographic and Health Surveys (DHS). The collected data was analyzed using the Statistical Package for Social Sciences (SPSS) software version 20.0.

Results: The results show that most construction workers have low HIV knowledge, low risk sexual behaviours and positive attitude towards HIV/AIDS. Furthermore, indicators of low knowledge were evident in awareness of PMTCT services, HIV can be spread through breastfeeding, HIV can be spread through sharing injection and HIV can be spread through unsafe sex.

Conclusion: In conclusion risk sexual behaviours are low, attitude towards HIV/AIDS is generally positive but HIV knowledge is low. However, there are alarming concerns in some indicators of both risk sexual behaviours and attitude noted in the study.

Keywords: HIV/AIDS, knowledge, risk behaviours, attitude, construction workers, Tanzania

\section{Introduction}

\subsection{Synopsis of HIV/AIDS Infection}

HIV/AIDS pandemic is a threat to the workforce not only in Tanzania but in the Sub-Saharan region. The UNAIDS Fact Sheet (2017) reports that globally, in 2016 there were 36.7 million people living with HIV, 1.8 million people became newly infected with HIV and 1million people died from AIDS-related diseases. Likewise, the UNAIDS Fact Sheet (2017) reports that in Eastern and Southern Africa there were 19.4 million people living with HIV, estimated 790000 new HIV infections and 420000 people died of AIDS-related diseases. Efforts have been in place to combat the infection resulting into global and regional decline in new HIV infection and AIDS related deaths. According to the UNAIDS Fact Sheet (2017) new HIV infections among adults declined by an estimated of $11 \%$ from 2010 to 2016 and AIDS-related deaths have fallen by $48 \%$ since the peak in 2005 globally. In East and Southern Africa, new HIV infections declined by $29 \%$ between 2010 and 2016 and the number of AIDS-related deaths in the region fell by $42 \%$ (ibid).

Tanzania which is part of East and Southern Africa is one among the severely affect countries. East and Southern Africa accounts for $43 \%$ of the global total of new HIV infections (UNAIDS Fact Sheet, 2017). According to Tanzania HIV Fact Sheet (2016) the HIV prevalence in Tanzania is estimated at 4.7\% and a total of 1.4 million Tanzanians were estimated to be living with HIV in 2015. Tanzania HIV Fact Sheet (2016) also reports that an estimated 54,000 new infections and 36,000 AIDS-related deaths occur in Tanzania annually. However, like in many parts of the world, new HIV infection and AIDS related deaths have been declining in Tanzania following a 
number of interventions instituted by the Government and other stakeholders. The TACAIDS et al. (2009 \& 2013) report state that HIV prevalence in Tanzania declined from $7 \%$ to $6 \%$ in 2008 and from $6 \%$ to $5 \%$ in 2011 . As of June 2011, an estimated 1.6 million people in Tanzania were living with HIV (TACAIDS et al., 2013).

\subsection{The Context of HIV/AIDS in the Construction Industry}

The HIV prevalence of $4.7 \%$ (Tanzania HIV Fact Sheet, 2016) in the population of Tanzania cannot leave the construction industry safe. Bowen et al. (2008) reports an HIV prevalence rate of $13.96 \%$ among construction employees and concludes that the industry has one of the highest prevalence rates of any economic sector. Bowen et al. (2015) point out that the construction industry is the third highest hit by HIV/AIDS after mining and transport. The construction industry depends mainly on labour to translate other resources into a physical object (i.e. building, road, airport etc.).The industry's workforce is always mobile and its activities are characterized by difficult working conditions. The mobile workforce and the nature of activities of the industry and their vulnerability to HIV/AIDS pandemic have been fairly researched. The construction industry is particularly vulnerable to the epidemic because of its migrant labour force, large unskilled labour force and aging workforce amongst other reasons (Harinarain \& Haupt, 2014). The HIV prevalence rates are increasing in many rural areas in which a significant proportion of the population migrates for work (Zhuang et al., 2012). The ILO (2008) explains that many studies have identified construction workers as a risk group along with miners and transport workers because many of them are mobile workers, with poor living and working conditions, and often separated from their families. Akinola et al. (2013) found that the vulnerability of migrant construction workers in India to HIV/AIDS were very high despite the high levels of HIV/AIDS knowledge and awareness. Migrant labour is a high risk group for HIV transmission in view of poor knowledge, high proportion of alcohol users among those reporting casual sex, and low proportion of condom use during non-regular sexual relationship (Arora et al., 2014). Qu et al. (2008) point out that the majority of construction workers in China comprise of floating population (migrant workers) exemplified by more males, younger age group, lower education level, more short-term and heavier labour. Weine \& Kashuba (2012) reveal that HIV risk among migrant labour was associated with multilevel determinants at the levels of policy, socio-cultural context, health and mental health, and sexual practices. Collectively, these studies reveal internal and external mobile workforce of the industry, poor living and working conditions and low levels of education. These reasons and many others subject the construction industry to the risk of HIV/AIDS infection.

\subsection{Construction Workers HIV/AIDS Knowledge, Risk Sexual Behaviours and Attitude}

Construction workers are exposed to HIV/AIDS and thus the need to explore concerns on the pandemic. These concerns include: HIV/AIDS knowledge, risk sexual behaviours as well as attitude. Researches worldwide have varying outcomes on knowledge, risk sexual behaviours and attitude towards HIV/AIDS. Qu et al. (2008) determine that majority of construction workers in China had poor knowledgeof HIV/AIDS and more than $60 \%$ had negative attitude towards people living with HIV/AIDS (PLWHA). Kanda et al. (2009) reveal that construction workers were familiar with the term HIV/AIDS but both internal and external migrant workers have a poor knowledge of HIV/AIDS and over 50\% respondents expressed discriminatory attitudes towards PLWHA. A study by Zhuang et al. (2012) reports high levels of sex with casual or commercial sex partners, low levels of consistent condom use with casual or commercial sex partners, and extremely low levels of condom use among those with stable partners which is a reflection of high risk sexual behaviours. Bowen et al. (2014) found that five firms believe they do not yet know enough about HIV/AIDS to make an informed decision about an effective HIV/AIDS policy or programme for their organization.

Haupt et al. (2005) report that both younger and older construction workers generally had acceptable levels of knowledge, perceptions and attitudes on most issues relative to the disease. However, the results of the study indicate that both age cohorts did not perceive HIV and AIDS as a serious problem at their workplace. Weine \& Kashuba (2012) found that the sexual practices most often associated with increased HIV risk were: limited condom use, multiple partnering, clients of sex workers, low HIV knowledge, and low perceived HIV risk. Bowen et al. (2016a) determine that prejudice and lifestyle risk are the terminal predictors of fear of testing. Kassa et al. (2013) study reveals that the prevalence of risky sexual behaviours among big construction enterprise workers was 44.9\%. Pant et al. (2013) found that construction workers had sufficient knowledge and more than half had positive attitude towards HIV/AIDS and concluded that attitude and use of condom were unsatisfactory. Purwaningsih et al. (2015) reveal that construction workers showed less knowledge, positive attitude, and less practice toward the risk of HIV transmission. Bowen et al. (2016b) found that HIV positive workers have poorer education levels and lower AIDS-related knowledge than non-infected workers.

The varying levels of knowledge, risky sexual behaviours and attitude towards HIV/AIDS among construction workers calls for further research in other parts of the world. Researches related to HIV/AIDS in the construction 
industry are almost non-existent in Tanzania. The current study seeks to fill this gap.

\section{Methods}

The study adopted a cross sectional research design. The population of the study was all active construction sites employing more than fifty workers. Purposive random sampling method was used to select sites for the study. The study was carried out in three regions of Tanzania including Dar es Salaam, Morogoro and Dodoma. Major reasons for selecting the three cities were the diversification and nature of construction sites, activities available in the selected areas and the easy access by the researchers. A sample size of 20 construction sites was chosen and 5 randomly selected respondents from each site were expected to fill the questionnaires. Out of 100 distributed questionnaires, 58 were fairly filled for the analysis which equates to $58 \%$.

The study adapted standard questionnaires developed by UNAIDS, Family Health International (FHI) and Demographic and Health Surveys (DHS). The questionnaires were translated from English to Swahili and self-administered during the study.The major variables for the study includes: background (age, sex, marital status, experience, occupation and current relationship); knowledge, risk sexual behaviours and attitude indicators.

The collected data was analyzed using the Statistical Package for Social Sciences (SPSS) software version 20.0. Descriptive statistics, recode into different variables and compute variables features were used to compute frequencies for background variables, indices and scales for indicators.

\section{Results}

Descriptive statistics, recode into different variables and compute variables features of SPSS were used to compute frequencies for background variables, knowledge, risky sexual behaviours and attitude indices and associated scales. The indices were developed to determine the extent to which various variables can be grouped together into a smaller number of indicators which summarizes the linear relationship between those variables. The scores of variables are set between 1 and 0 . The numbers of variables selected for developing the indices are 11, 9 and 15 for knowledge, risky sexual behaviours and attitude respectively. The total scores are between 0 and 12 for knowledge, 0 and 10 for risky sexual behaviours and 0 and 16 for attitude. The indices for knowledge, risky sexual behaviours and attitude are as shown in Table 1.

Table 1. Indices for knowledge, sexual risk behaviours and attitude

\begin{tabular}{|c|c|c|c|c|c|c|c|c|}
\hline \multicolumn{3}{|c|}{ Index of knowledge } & \multicolumn{3}{|c|}{ Index of risk behaviours } & \multicolumn{3}{|c|}{ Index of attitude } \\
\hline & Frequency & Percent & & Frequency & Percent & & Frequency & Percent \\
\hline 1 & 2 & 3.4 & 0 & 2 & 3.4 & 1 & 1 & 1.7 \\
\hline 2 & 5 & 8.6 & 1 & 13 & 22.4 & 4 & 1 & 1.7 \\
\hline 3 & 10 & 17.2 & 2 & 12 & 20.7 & 5 & 3 & 5.2 \\
\hline 4 & 19 & 32.8 & 3 & 12 & 20.7 & 6 & 2 & 3.4 \\
\hline 5 & 14 & 24.1 & 4 & 10 & 17.2 & 7 & 8 & 13.8 \\
\hline 6 & 7 & 12.1 & 5 & 6 & 10.3 & 8 & 1 & 1.7 \\
\hline 7 & 1 & 1.7 & 6 & 3 & 5.2 & 9 & 3 & 5.2 \\
\hline \multirow[t]{7}{*}{ Total } & 58 & 100.0 & Total & 58 & 100.0 & 10 & 7 & 12.1 \\
\hline & & & & & & 11 & 11 & 19.0 \\
\hline & & & & & & 12 & 3 & 5.2 \\
\hline & & & & & & 13 & 9 & 15.5 \\
\hline & & & & & & 14 & 5 & 8.6 \\
\hline & & & & & & 15 & 4 & 6.9 \\
\hline & & & & & & Total & 58 & 100.0 \\
\hline
\end{tabular}

To develop the scale for knowledge, risky sexual behaviours and attitude towards HIV/AIDS the following score ranges were determined:

a) 0-4 low knowledge and 5 and above high knowledge. In calculating the scale for index new score ranges redefined as Lowest through $4=1,5$ through Highest $=2$

b) $4=$ low risk sexual behaviours and 5 and above $=$ high risk sexual behaviours. In calculating the scale for index new score ranges redefined as Lowest through 4=1, 6 through Highest $=2$ 
c) $\quad 0-7=$ Negative attitude, 8 and above $=$ Neutral attitude and 6 and above $=$ positive attitude. In calculating the scale for index new score ranges redefined as Lowest through 7=1,8 through Highest $=2$. The results are presented in Table 2.

Table 2. Scales for knowledge, risky sexual behaviours and attitude

\begin{tabular}{lll}
\hline Scale for HIV/AIDS knowledge & Frequency & Percent \\
\hline Low knowledge & 36 & 62.1 \\
High knowledge & 22 & 37.9 \\
Total & $\mathbf{5 8}$ & $\mathbf{1 0 0 . 0}$ \\
Scale for HIV/AIDS risk sexual behaviours & & \\
Low risk sexual behaviours & 37 & 63.8 \\
High risk sexual behaviours & 21 & 36.2 \\
Total & $\mathbf{5 8}$ & $\mathbf{1 0 0 . 0}$ \\
Scale for attitude towards HIV/AIDS & & \\
Negative attitude & 15 & 25.8 \\
Positive attitude & 43 & 74.2 \\
Total & $\mathbf{5 8}$ & $\mathbf{1 0 0 . 0}$ \\
\hline
\end{tabular}

\subsection{General Knowledge, Sexual Risk Behaviours and Attitude}

Background variables and associated knowledge, risk sexual behaviours and attitude are shown in Table 3. With participation of $63.8 \%$ male and $36.2 \%$ female, knowledge of HIV/AIDS and risk sexual behaviours were generally low. Furthermore, there is no significant difference between male and female general knowledge on HIV/AIDS and risk sexual behaviours. Attitude towards HIV/AIDS was generally positive and there was a significant difference across sex with female having more positive attitude than male. In terms of married (57.1\%) and others (42.9\%) general knowledge on HIV/AIDS was low, risk sexual behaviours was low and attitude towards HIV/AIDS was positive and there was no significant difference on the assessed indicators between the two groups. Other background variables namely age group, experience and trade the results were similar to married and others with the exception of attitude towards HIV/AIDS in trade group. Attitude towards HIV/AIDS among skilled and unskilled respondents was significantly different with skilled exhibiting more positive attitude towards HIV/AIDS than unskilled. 
Table 3. Background variables and general knowledge, risk sexual behaviours and attitude

\begin{tabular}{|c|c|c|c|c|c|c|c|c|c|c|c|c|}
\hline \multirow{2}{*}{ Factor } & \multicolumn{4}{|c|}{ Knowledge } & \multicolumn{4}{|c|}{ Risk sexual behaviours } & \multicolumn{4}{|c|}{ Attitude towards HIV/AIDS } \\
\hline & Low & High & Total & Sig & Low & High & Total & Sig & $-\mathrm{Ve}$ & $+\mathrm{Ve}$ & Total & sig \\
\hline \multicolumn{13}{|l|}{$\operatorname{Sex}$} \\
\hline Male & $41.4 \%$ & $22.4 \%$ & $63.8 \%$ & .380 & $53.5 \%$ & $10.3 \%$ & $63.8 \%$ & .581 & $22.4 \%$ & $41.4 \%$ & $63.8 \%$ & $.030^{*}$ \\
\hline Female & $20.7 \%$ & $15.5 \%$ & $36.2 \%$ & & $31 \%$ & $5.2 \%$ & $36.2 \%$ & & $3.4 \%$ & $32.8 \%$ & $36.2 \%$ & \\
\hline Total & $62.1 \%$ & $37.9 \%$ & $100 \%$ & & $63.8 \%$ & $36.2 \%$ & $100 \%$ & & $25.8 \%$ & $74.2 \%$ & 100 & \\
\hline \multicolumn{13}{|l|}{ Marital } \\
\hline \multicolumn{13}{|l|}{ status } \\
\hline Married & $32.1 \%$ & $25.0 \%$ & $57.1 \%$ & .121 & $44.6 \%$ & $12.5 \%$ & $57.1 \%$ & .064 & $17.9 \%$ & $39.3 \%$ & $57.1 \%$ & .288 \\
\hline Others & $32.2 \%$ & $10.7 \%$ & $42.9 \%$ & & $41.1 \%$ & $1.8 \%$ & $42.9 \%$ & & $8.9 \%$ & $33.9 \%$ & $42.9 \%$ & \\
\hline Total & $64.3 \%$ & $35.7 \%$ & $100 \%$ & & $85.7 \%$ & $14.3 \%$ & $100 \%$ & & $26.8 \%$ & $73.2 \%$ & $100 \%$ & \\
\hline \multicolumn{13}{|l|}{ Age group } \\
\hline $15-24$ & $29.3 \%$ & $13.8 \%$ & $43.1 \%$ & .297 & $34.5 \%$ & $8.6 \%$ & $43.1 \%$ & .322 & $8.6 \%$ & $34.5 \%$ & $43.1 \%$ & .282 \\
\hline \multicolumn{13}{|l|}{ years old } \\
\hline Over 24 & $32.8 \%$ & $24.1 \%$ & $56.9 \%$ & & $50.0 \%$ & $6.9 \%$ & $56.9 \%$ & & $17.2 \%$ & $39.7 \%$ & $56.9 \%$ & \\
\hline \multicolumn{13}{|l|}{ years old } \\
\hline Total & $62.1 \%$ & $37.9 \%$ & $100 \%$ & & $84.5 \%$ & $15.5 \%$ & $100 \%$ & & $25.8 \%$ & $74.2 \%$ & $100 \%$ & \\
\hline Experience & & & & .492 & & & & .468 & & & & \\
\hline Less than 5 & $38.5 \%$ & $21.1 \%$ & $59.6 \%$ & & $49.1 \%$ & $10.5 \%$ & $59.6 \%$ & & $19.3 \%$ & $40.4 \%$ & $59.7 \%$ & .171 \\
\hline \multicolumn{13}{|l|}{ years } \\
\hline Over 5 & $24.6 \%$ & $15.8 \%$ & $40.4 \%$ & & $35.1 \%$ & $5.3 \%$ & $40.4 \%$ & & $7.0 \%$ & $33.3 \%$ & $40.3 \%$ & \\
\hline \multicolumn{13}{|l|}{ years } \\
\hline Total & $63.1 \%$ & $36.9 \%$ & $100 \%$ & & $84.2 \%$ & 36.8 & $100 \%$ & & $26.3 \%$ & $73.7 \%$ & $100 \%$ & \\
\hline Trade & & & & .289 & & & & .185 & & & & $.025^{* *}$ \\
\hline Skilled & $41.4 \%$ & $29.3 \%$ & $70.7 \%$ & & $56.9 \%$ & $13.8 \%$ & $70.7 \%$ & & $12.1 \%$ & $58.6 \%$ & $70.7 \%$ & \\
\hline Unskilled & $20.7 \%$ & $8.6 \%$ & $29.3 \%$ & & $27.6 \%$ & $1.7 \%$ & $29.7 \%$ & & $13.8 \%$ & $15.5 \%$ & $29.3 \%$ & \\
\hline Total & $62.1 \%$ & $37.9 \%$ & $100 \%$ & & $84.5 \%$ & $15.5 \%$ & $100 \%$ & & & & & \\
\hline
\end{tabular}

\subsection{General Knowledge, Risk Sexual Behaviours and Attitude for All Variables}

Table 4 presents respondents general knowledge, risk sexual behaviours and attitude on individual indicators. Respondents' knowledge on HIV and AIDS was significantly different in the following indicators: Are you aware of PMTCT Services (sig= 0.045); HIV can be spread through breastfeeding (sig=0.000); HIV can be spread through injection ( $\mathrm{sig}=0.06$ ), and HIV can be spread through unsafe sex $(\mathrm{sig}=0.000)$. The HIV Knowledge of assessed indicators is daunting among those with low and high knowledge. Awareness of PMTCT Services is such that $36.2 \%$ and $12.1 \%$ of those with low and high knowledge respectively are not aware. HIV can be spread through breastfeeding, all $22 \%$ respondents with high knowledge agreed that a baby can contract HIV through breastfeeding while $62.1 \%$ and $15.5 \%$ of both low and high knowledge did not. HIV can be spread through sharing injection was not acknowledged by $39.7 \%$ with low knowledge and $5.2 \%$ with high knowledge and almost the same trend (31\% and 5.2\%) was noted for HIV spread through unsafe sex.

Respondents risk sexual behaviours were significantly different in the following indicators: ever engaged in sexual relationship with a person who is not your spouse in the past three months (sig $=0.000)$; condom was used while having sex with a person who is not your spouse (sig= 0.000$)$; do you have multiple sex partners? $(\mathrm{sig}=0.000)$ and ever had anal sex with any of your multiple sex partners ( $\mathrm{sig}=0.022$ ). Despite general low risk sexual behaviours determined in the present study, risk sexual behaviours is still rampant in some of the indicators. Engagement in sexual relationship with a person who is not one's spouse in the past three months prior to the study was noted in $25.9 \%$ of those with low risk sexual behaviours and $15.5 \%$ of those with high risk behaviours. Majority (63.8\%) of 
those with low risk behaviours did not use condom during the first time of sexual intercourse. Multiple sex partners practice was revealed in $19 \%$ and $15.5 \%$ of those with low and high risk sexual behaviours respectively. Respondents with low risk sexual behaviours (44.8\%) and high risk behaviuors (12.1\%) disclosed that it is common for fellow construction workers to have multiple sex partners.

Respondents' attitude towards HIV/AIDS was significantly different between those with negative and positive attitudes inalmost all assessed indicators. Indicators which were statistically insignificant are: discussion of HIV/AIDS with family (sig= 0.172), discussion of HIV/AIDS with friends $(\mathrm{sig}=0.151)$ readiness to buy food knowingly from an HIV infected food vendor (sig= 0.151) and refusing sex without condom with one's sexual partner (sig= 0.438). Disparity was noted between those with negative and positive attitude towards HIV/AIDS. Respondents with negative attitude (19\%) and positive attitude (24.1\%) cannot share food with HIV infected person). Nineteen per cent and $13.8 \%$ of respondents with negative and positive attitude respectively indicated that an HIV infected boss should not be allowed to continue working in the company. More than $36 \%$ of respondents with positive attitude wish it to remain a secret if one of the family members is HIV infected. Never tested for HIV was noted in $22.4 \%$ of those with negative attitude and $10.3 \%$ of those with positive attitude and nearly the same trend was noted in never given the HIV test results $(24.1 \%$ negative attitude and $13.8 \%$ positive attitude).Disclosure of HIV test results were such that $24.1 \%$ of those with negative attitude and $22.4 \%$ positive attitudes never revealed HIV results to anyone and the trend was more or less the same with their readiness to disclose their HIV positive test results (20.7\% negative attitude and $10.3 \%$ positive attitude). Furthermore, $13.8 \%$ of respondents with negative attitude and $34.5 \%$ of those with positive attitude never refused sex without condom.

Table 4. Knowledge, risk sexual behaviours and attitude indicators

\begin{tabular}{|c|c|c|c|c|c|c|c|c|c|c|c|}
\hline \multirow[t]{2}{*}{$\mathbf{S} / \mathbf{N}$} & \multirow[t]{2}{*}{ Variable } & & \multicolumn{3}{|c|}{ Knowledge } & \multicolumn{3}{|c|}{ Risk sexual behaviours } & \multicolumn{3}{|c|}{ Attitude towards H\&S } \\
\hline & & & Low & High & Sig & Low & High & Sig & $-\mathrm{Ve}$ & $+\mathrm{Ve}$ & Sig \\
\hline \multirow[t]{2}{*}{ K1 } & \multirow{2}{*}{$\begin{array}{l}\text { Are you aware of HIV } \\
\text { and AIDS? }\end{array}$} & Yes & $60.3 \%$ & $37.9 \%$ & .621 & & & & & & \\
\hline & & No & $1.7 \%$ & $0 \%$ & & & & & & & \\
\hline \multirow[t]{2}{*}{ K2 } & \multirow{2}{*}{$\begin{array}{l}\text { Can ARVs Cure } \\
\text { AIDS? }\end{array}$} & Yes & $6.9 \%$ & $10.3 \%$ & .112 & & & & & & \\
\hline & & No & $55.2 \%$ & $27.6 \%$ & & & & & & & \\
\hline \multirow[t]{2}{*}{ K3 } & \multirow{2}{*}{$\begin{array}{l}\text { HIV positive mother } \\
\text { can give birth to HIV } \\
\text { negative baby }\end{array}$} & Yes & $51.7 \%$ & $36.2 \%$ & .170 & & & & & & \\
\hline & & No & $10.3 \%$ & $1.7 \%$ & & & & & & & \\
\hline \multirow[t]{2}{*}{ K4 } & \multirow{2}{*}{$\begin{array}{l}\text { Are you aware of } \\
\text { PMTCT Services }\end{array}$} & Yes & $25.9 \%$ & $25.9 \%$ & $.045^{*}$ & & & & & & \\
\hline & & No & $36.2 \%$ & $12.1 \%$ & & & & & & & \\
\hline \multirow[t]{2}{*}{ K5 } & \multirow{2}{*}{$\begin{array}{l}\text { HIV and AIDS can be } \\
\text { spread through saliva }\end{array}$} & Yes & $1.7 \%$ & $3.4 \%$ & .319 & & & & & & \\
\hline & & No & $60.3 \%$ & $34.5 \%$ & & & & & & & \\
\hline \multirow[t]{2}{*}{ K6 } & \multirow{2}{*}{$\begin{array}{l}\text { HIV and AIDS can be } \\
\text { spread through } \\
\text { sharing food }\end{array}$} & Yes & $1.7 \%$ & $0 \%$ & .621 & & & & & & \\
\hline & & No & $60.3 \%$ & $37.9 \%$ & & & & & & & \\
\hline \multirow[t]{2}{*}{ K7 } & \multirow{2}{*}{$\begin{array}{l}\text { HIV and AIDS can be } \\
\text { spread through } \\
\text { sharing utensils }\end{array}$} & Yes & $1.7 \%$ & $0 \%$ & .621 & & & & & & \\
\hline & & No & $60.3 \%$ & $0 \%$ & & & & & & & \\
\hline \multirow[t]{2}{*}{ K8 } & \multirow{2}{*}{$\begin{array}{l}\text { HIV can be spread } \\
\text { through breastfeeding }\end{array}$} & Yes & $0 \%$ & $22.4 \%$ & $.000 * *$ & & & & & & \\
\hline & & No & $62.1 \%$ & $15.5 \%$ & & & & & & & \\
\hline \multirow[t]{2}{*}{ K9 } & \multirow{2}{*}{$\begin{array}{l}\text { HIV can be spread } \\
\text { through } \\
\text { injection }\end{array}$} & Yes & $22.4 \%$ & $32.8 \%$ & $.000 * *$ & & & & & & \\
\hline & & No & $39.7 \%$ & $5.2 \%$ & & & & & & & \\
\hline \multirow[t]{2}{*}{ K10 } & \multirow{2}{*}{$\begin{array}{l}\text { HIV can be spread } \\
\text { through living with } \\
\text { infected person }\end{array}$} & Yes & $0 \%$ & $1.7 \%$ & .379 & & & & & & \\
\hline & & No & $62.1 \%$ & $36.2 \%$ & & & & & & & \\
\hline
\end{tabular}




\begin{tabular}{|c|c|c|c|c|c|c|c|c|c|c|c|}
\hline \multirow[t]{2}{*}{ K11 } & \multirow{2}{*}{$\begin{array}{l}\text { HIV can be spread } \\
\text { through unsafe sex }\end{array}$} & Yes & $31.0 \%$ & $32.8 \%$ & \multirow{2}{*}{\multicolumn{2}{|c|}{$0.06 * *$}} & & & & & \\
\hline & & No & $31.0 \%$ & $5.2 \%$ & & & & & & & \\
\hline \multirow[t]{2}{*}{ B1 } & \multirow{2}{*}{$\begin{array}{l}\text { The respondent never } \\
\text { had sexual intercourse }\end{array}$} & Yes & & & & $10.3 \%$ & $0 \%$ & .345 & & & \\
\hline & & No & & & & $74.1 \%$ & $15.5 \%$ & & & & \\
\hline \multirow[t]{2}{*}{ B 2} & \multirow{2}{*}{$\begin{array}{l}\text { First sexual } \\
\text { intercourse was done } \\
\text { willingly }\end{array}$} & Yes & & & & $62.1 \%$ & $13.8 \%$ & .300 & & & \\
\hline & & No & & & & $22.4 \%$ & $1.7 \%$ & & & & \\
\hline \multirow[t]{2}{*}{ B 3} & \multirow{2}{*}{$\begin{array}{l}\text { Condom was used } \\
\text { during the first time } \\
\text { sexual intercourse }\end{array}$} & Yes & & & & $20.7 \%$ & $10.3 \%$ & .425 & & & \\
\hline & & No & & & & $63.8 \%$ & $5.2 \%$ & & & & \\
\hline \multirow[t]{2}{*}{ B 4} & \multirow[t]{2}{*}{ Ever had anal sex } & Yes & & & & $0 \%$ & $1.7 \%$ & .155 & & & \\
\hline & & No & & & & $84.5 \%$ & $13.8 \%$ & & & & \\
\hline \multirow[t]{2}{*}{ B 5} & \multirow{2}{*}{$\begin{array}{l}\text { Ever engaged in sexual } \\
\text { relationship with a } \\
\text { person who is not your } \\
\text { spouse in the past three } \\
\text { months }\end{array}$} & Yes & & & & $25.9 \%$ & $15.5 \%$ & $.000^{* *}$ & & & \\
\hline & & No & & & & $58.6 \%$ & $0 \%$ & & & & \\
\hline \multirow[t]{2}{*}{ B 6} & \multirow{2}{*}{$\begin{array}{l}\text { Condom was used } \\
\text { while having sex with } \\
\text { a person who is not } \\
\text { your spouse }\end{array}$} & Yes & & & & $72.4 \%$ & $0 \%$ & $.000^{* *}$ & & & \\
\hline & & No & & & & $12.1 \%$ & $15.5 \%$ & & & & \\
\hline \multirow[t]{2}{*}{ B 7} & \multirow{2}{*}{$\begin{array}{l}\text { Do you have multiple } \\
\text { sex partners? }\end{array}$} & Yes & & & & $19 \%$ & $15.5 \%$ & $.000 * *$ & & & \\
\hline & & No & & & & $65.5 \%$ & $0 \%$ & & & & \\
\hline \multirow[t]{2}{*}{ B 8} & \multirow{2}{*}{$\begin{array}{l}\text { Ever had anal sex with } \\
\text { any of your multiple } \\
\text { sex partners? }\end{array}$} & Yes & & & & $0 \%$ & $3.4 \%$ & $.022 * *$ & & & \\
\hline & & No & & & & $84.5 \%$ & $12.1 \%$ & & & & \\
\hline \multirow[t]{2}{*}{ B 9} & \multirow{2}{*}{$\begin{array}{l}\text { Is it common for } \\
\text { fellow construction } \\
\text { workers to have } \\
\text { multiple sex partners? }\end{array}$} & Yes & & & & $44.8 \%$ & $12.1 \%$ & .157 & & & \\
\hline & & No & & & & $39.7 \%$ & $3.4 \%$ & & & & \\
\hline \multirow[t]{2}{*}{ A1 } & \multirow{2}{*}{$\begin{array}{l}\text { Do you discuss HIV / } \\
\text { AIDS with family? }\end{array}$} & Yes & & & & & & & $17.2 \%$ & $62.1 \%$ & .151 \\
\hline & & No & & & & & & & $8.6 \%$ & $12.1 \%$ & \\
\hline \multirow[t]{2}{*}{ A2 } & \multirow{2}{*}{$\begin{array}{l}\text { Do you discuss HIV / } \\
\text { AIDS with friends? }\end{array}$} & Yes & & & & & & & $20.7 \%$ & $69.0 \%$ & .172 \\
\hline & & No & & & & & & & $5.2 \%$ & 5.2 & \\
\hline \multirow[t]{2}{*}{ A3 } & \multirow{2}{*}{$\begin{array}{l}\text { Do you know anyone } \\
\text { who died from HIV? }\end{array}$} & Yes & & & & & & & $13.8 \%$ & $62.1 \%$ & $.033^{* *}$ \\
\hline & & No & & & & & & & $21.1 \%$ & $12.1 \%$ & \\
\hline A4 & Are you ready to & Yes & & & & & & & $6.9 \%$ & $50.0 \%$ & $.014 * *$ \\
\hline & $\begin{array}{l}\text { shared food with HIV } \\
\text { and AIDS infected } \\
\text { person? }\end{array}$ & No & & & & & & & $19 \%$ & $24.1 \%$ & \\
\hline A5 & Are you ready to share & Yes & & & & & & & $20.7 \%$ & $72.4 \%$ & $.049^{* *}$ \\
\hline & working tools with & No & & & & & & & $5.2 \%$ & $1.7 \%$ & \\
\hline & infected person? & No & & & & & & & $19 \%$ & $13.8 \%$ & \\
\hline A6 & $\begin{array}{l}\text { An HIV infected boss } \\
\text { should be allowed to } \\
\text { continue working in } \\
\text { the company? }\end{array}$ & Yes & & & & & & & $6.9 \%$ & $60.3 \%$ & $.000 * *$ \\
\hline
\end{tabular}




\begin{tabular}{|c|c|c|c|c|c|}
\hline \multirow[t]{2}{*}{ A7 } & \multirow{2}{*}{$\begin{array}{l}\text { Are you ready to buy } \\
\text { food knowingly from } \\
\text { an HIV infected food } \\
\text { vendor? }\end{array}$} & Yes & $17.2 \%$ & $62.1 \%$ & \multirow[t]{2}{*}{.151} \\
\hline & & No & $8.6 \%$ & $12.1 \%$ & \\
\hline \multirow[t]{2}{*}{ A8 } & \multirow{2}{*}{$\begin{array}{l}\text { Would you wish it to } \\
\text { remain a secret if one } \\
\text { of the family member } \\
\text { is HIV infected }\end{array}$} & Yes & $5.2 \%$ & $36.2 \%$ & \multirow[t]{2}{*}{$.047^{*}$} \\
\hline & & No & $20.7 \%$ & $37.9 \%$ & \\
\hline \multirow[t]{2}{*}{ A9 } & \multirow{2}{*}{$\begin{array}{l}\text { Have you ever tested } \\
\text { for HIV and AIDS? }\end{array}$} & Yes & $3.4 \%$ & $63.8 \%$ & \multirow[t]{2}{*}{$.000^{* *}$} \\
\hline & & No & $22.4 \%$ & $10.3 \%$ & \\
\hline \multirow[t]{2}{*}{ A10 } & \multirow{2}{*}{$\begin{array}{l}\text { Were you given results } \\
\text { after testing for HIV }\end{array}$} & Yes & $1.7 \%$ & $60.3 \%$ & \multirow[t]{2}{*}{$000^{* *}$} \\
\hline & & No & $24.1 \%$ & $13.8 \%$ & \\
\hline \multirow[t]{2}{*}{ A11 } & \multirow{2}{*}{$\begin{array}{ll}\text { Have you ever } \\
\text { revealed the test } \\
\text { results to anyone }\end{array}$} & Yes & $1.7 \%$ & $51.7 \%$ & \multirow[t]{2}{*}{$.000^{* *}$} \\
\hline & & No & $24.1 \%$ & $22.4 \%$ & \\
\hline \multirow[t]{2}{*}{ A12 } & \multirow{2}{*}{$\begin{array}{l}\text { Would you wish to test } \\
\text { again for HIV }\end{array}$} & Yes & $20.7 \%$ & $58.6 \%$ & \multirow[t]{2}{*}{$.000^{* *}$} \\
\hline & & No & $5.2 \%$ & $15.5 \%$ & \\
\hline \multirow[t]{2}{*}{ A13 } & Are you ready to & Yes & $5.2 \%$ & $63.8 \%$ & \multirow[t]{2}{*}{$.000^{* *}$} \\
\hline & $\begin{array}{l}\text { reveal your positive } \\
\text { HIV results to another } \\
\text { person }\end{array}$ & No & $20.7 \%$ & $10.3 \%$ & \\
\hline \multirow[t]{2}{*}{ A14 } & Is it proper for & Yes & $13.8 \%$ & $65.5 \%$ & \multirow[t]{2}{*}{$.008^{* *}$} \\
\hline & $\begin{array}{l}\text { unmarried women to } \\
\text { buy condom whenever } \\
\text { they need to have }\end{array}$ & No & $21.1 \%$ & $8.6 \%$ & \\
\hline \multirow[t]{2}{*}{ A15 } & \multirow{2}{*}{$\begin{array}{l}\text { Have you ever refused } \\
\text { sex without condom } \\
\text { with your sexual } \\
\text { partner }\end{array}$} & Yes & $12.1 \%$ & $39.7 \%$ & \multirow[t]{2}{*}{.438} \\
\hline & & No & $13.8 \%$ & $34.5 \%$ & \\
\hline
\end{tabular}

\section{Discussion}

The participation of male (63.8\%)wasmore than female $(36.2 \%)$ which is consistent with previous studies (Arora et al., 2014; Bowen et al., 2016a; Haupt et al., 2005; Purwaningsih et al.,2015; Bowen et al., 2016b; Bowen et al., 2015; Kassa et al., 2013; Pant et al., 2013; Kanda et al., 2009). This mirrors the male domination of the industry. The HIV/AIDS knowledge of respondents was generally low same as determined in the works of Arora et al. (2014), Qu et al. (2008), Purwaningsih et al. (2015) and Bowen et al. (2016a) contrary to those of Pant et al. (2013), Akinola et al. (2013), Haupt et al. (2005) and Kanda et al. (2009).The disparity in the findings of HIV knowledge in the current study and previous studies is mostly influence by the indicators assessed. Risky sexual behaviours were generally low which supports the studies of Akinola et al. (2013) and Purwaningsih et al. (2015) but contradicts the works of Kassa et al. (2013), Arora et al. (2014), Haupt et al. (2005), Qu et al. (2008) and Zhuang et al. (2012). Furthermore, there is no statistical significance difference across groupings (i.e. male and female; married and others; age group; experience; and trade) on the general HIV knowledge, risk sexual behaviours and attitude except attitude in the sex and trade categories. Further to this finding, females are reported to have lower levels of HIV/AIDS knowledge compared to their male counterparts in studies of TACAIDS et al. (2013), Pant et al. (2013) and Arora et al. (2014) and higher risky sexual behaviors in the study of Kassa et al. (2013).

Attitude towards HIV/AIDS was generally positive which is consistent with the previous studies of Pant et al. (2013) and Purwaningsih et al. (2015) and contrary to those of Qu et al. (2008) and Kanda et al. (2009). However, there was statistical significant difference across sex with female having more positive attitude than male. This contradicts other studies such as Pant et al. (2013) and TACAIDSet al. (2013) which report that females have more negative attitude towards HIV/AIDS than males. Similarly, attitude towards HIV/AIDS among skilled and unskilled respondents was significant different with skilled exhibiting more positive attitude towards HIV/AIDS 
than unskilled. This finding supports the study of Kanda et al. (2009) which found that those with lower levels of education had negative attitude.

Previous studies have assessed various indicators of HIV/AIDS knowledge, risky sexual behaviours and attitude. In the present study it was established that HIV knowledge among respondents with low and high HIV knowledge differ significantly on awareness of PMTCT Services, HIV spread through breastfeeding, and HIV spread through sharing injection and having unsafe sex. There are noted lower HIV knowledge areas for both respondents categorized with low and high general knowledge. About $50 \%$ of respondents are not aware of PMTCT Services. Respondents, $44.9 \%$ and $36.2 \%$ indicated that HIV cannot spread through sharing injection and having unsafe sex.

Respondents with low and high risky sexual behaviours had significant differences of behaviour on involvement in sexual relationship with a person who is not one's spouse in the past three months, use of condom while having sex with a person who is not one's spouse, having multiple sex partners, and or having anal sex with any of one's multiple sex partners. Risky sexual behaviours were noted across indicators for both respondents with low and high risk behaviours. Engagement in sexual relationship with a person who is not one's spouse in the past three months prior to the study was noted in $41.4 \%$ respondents. Majority $(63.8 \%)$ of those with low risk behaviours did not use condom during the first time sexual intercourse. Multiple sex partners practice was revealed in $34.5 \%$ of respondents. More than $50 \%$ of respondents disclosed that it is common for fellow construction workers to have multiple sex partners.

Respondents with negative and positive attitudes towards HIV/AIDS, their attitude was significantly different in almost all indicators except for discussion of HIV/AIDS with family and friends, readiness to buy food knowingly from an HIV infected food vendor and refusing sex without condom with one's sexual partner. Negative attitude was noted among respondents with both general negative and positive attitude in some of the indicators. More than $40 \%$ respondents are ready to share food with HIV and AIDS infected person. An HIV infected boss should not be allowed to continue working in the company was noted in $32.8 \%$ of the respondents. Wishing it to remain a secret if one of the family members is HIV infected was indicated by $36.2 \%$. Respondents who never tested, never given results, not revealed HIV results to anyone and not ready to reveal their positive HIV results to another person account for $32.7 \%, 37.9 \%, 46 . \%$ and $31 \%$ respectively. Furthermore, $48.3 \%$ of the respondents never refused sex without condom.

\section{Conclusion}

The construction workers HIV knowledge, risk sexual behaviours and attitude towards HIV/AIDS in Tanzania were evaluated. General knowledge of HIV/AIDS is low and the alarming indicators are: awareness of PMTCT Services, HIV spread through breastfeeding, HIV spread through injection, andHIV spread through unsafe sex. Risk sexual behaviours were generally low but disparity was noted in engagement in sexual relationship with a person who is not one's spouse in the past three months prior to the study, use of condom during the first time sexual intercourse, multiple sex partners practice, noted behaviours of construction workers to have multiple sex partners. Attitude towards HIV/AIDS is generally positive but there are few areas that have remained of concern such as readiness to shared food with HIV and AIDS infected person, an HIV infected boss to be allowed to continue working in the company, wishing to remain a secret if one of the family members is HIV infected, testing for HIV, seeking for results after HIV testing, revealing HIV results to anyone, readiness to reveal positive HIV results to another person, and, refused sex without condom.

\section{Ethical Considerations}

Permission to conduct the study was provided by the Directorate of Postgraduate Research and Publications of Ardhi University. No other personal information such as name and address was obtained. The respondents were clearly informed of the objective of the study as well as requested consent in participating in the research through an introductory note on the questionnaire. Filling in the questionnaire indicated acceptance of participation.

\section{Competing Interests Statement}

The authors declare that they have no competing or potential conflicts of interest regarding the publication of this paper.

\section{References}

Akinola, A. B., Krishna, A. K. I., \&Chetlapalli, S. K. (2013). Vulnerability profile of migrant construction workers to HIV/AIDS in an urban area in south India - a cross sectional study. IOSR Journal of Humanities and Social Science, 17(4), 75-77. Retrieved 11 July, 2017, from, www.iosrjournals.org

Arora, V. K., Sharma, S., \& Mahashabde, P. (2014). Sexual behaviour among migrant construction workers in 
Indore. International Journal of Medical Science and Public Health, 3(5), 574-577. https://doi.org/10.5455/ijmsph.2014.110320142

Bowen, P., Allen, Y., Edwards, P., Cattell, K., \& Simbayi, L. (2014) Guidelines for effective workplace HIV/AIDS intervention management by construction firms. Construction Management and Economics, 32(4), 362-381, https://doi.org/10.1080/01446193.2014.883080

Bowen, P., Dorrington, R., Distiller, G., Harry, L., \& Besesar, S. (2008). HIV/AIDS in the South African Construction Industry: An Empirical Study. Journal of Construction Management and Economics, 26(8), 827-839. https://doi.org/10.1080/01446190802061225

Bowen, P., Govender, R., Edwards, P., \&Cattell, K. (2016a). An explanatory model of attitudinal fear of HIV/AIDS testing in the construction industry. Engineering, Construction and Architectural Management, 23(1), 92-112. https://doi.org/10.1108/ECAM-10-2014-0134

Bowen, P., Govender, R., Edwards, P., \& Cattell, K. (2016b) Demographic and Lifestyle Determinants of the HIV Serostatus of Construction Workers. In: P W Chan and C J Neilson (Eds.) Proceedings of the 32nd Annual ARCOM Conference, 5-7 September 2016, Manchester, UK, Association of Researchers in Construction Management, $\quad 1, \quad 507-517 . \quad$ Retrieved 26th July, 2017, from http://www.arcom.ac.uk/-docs/proceedings/d88f64d0f37e3c3275dadb78656a4286.pdfc

Bowen, P., Govender, R., Edwards, P., \& Cattell, K. (2015). HIV testing of construction workers in the Western Cape, South Africa. AIDS Care, 27(9), 1150-1155.https://doi.org/10.1080/09540121.2015.1032877

Harinarain, N., \& Haupt, T. C. (2014). The vulnerability of the construction industry to HIV and AIDS. Journal of construction, 7(2), 61-66. Retrieved 14th August, 2017, from http://www.asocsa.org/documents/JoC-Dec2014-vol7-no2.pdf

Haupt, T. C., Munshi, M., \& Smallwood, J. (2005). HIV and AIDS in South African construction: Is age nothing but a number. Construction Management and Economics, 23(1), 107-120. https://doi.org/10.1080/0144619042000301366

ILO. (2008). Guidelines for the construction sector. Retrieved 22nd May, 2015, from, http://www.ilo.org/wcmsp5/groups/public/---ed_protect/---protrav/---ilo_aids/documents/publication/wcms_ 115123.pdf

Kanda, K., Obayashi, Y., Ditangco R. A., Matibag, G. C., Yamashina H., Okumura, S. K., Tudor Silva, K. S., \& Tamashiro, H. (2009). Knowledge, attitude and practice assessment of construction workers for HIV/AIDS in Sri Lanka. Journal of Infection in developing countries, 3(8). 611-619. Retrieved 24th August, 2017, form $\mathrm{http} / / /$ www.academia.edu/11257768/Knowledge_attitude_and_practice_assessment_of_construction_worke rs_for_HIV_AIDS_in_Sri_Lanka

Kassa, M., Tesfaye, E., \& Alamrew, Z. (2013). Risky sexual behaviour among big construction enterprise workers; Bahir Dar City, Amhara Regional State, Northwest Ethiopia. International Journal of Clinical Medicine, 4(6), 296-303. https://doi.org/10.4236/ijcm.2013.46052

Pant, A., Kanato, M., Thapa, P., \&Ratanasiri, A. (2013). Knowledge of and Attitude towards HIV/AIDS and Condom Use among Construction Workers in the Kathmandu Valley, Nepal. Journal of Medical Association Thai, 96(4), 107-116. Retrieved 14th August, 2017, from https://kkucleft.kku.ac.th/research/JMAT_FINAL/JMAT\%20Final\%202013/S107-S116_PS18.pdf

Purwaningsih, P., Qur'aniati, N., \& Efendi, F. (2015). The effectiveness of behavioral change communication (BCC) program to change HIV/AIDS-related behaviors on construction workers. International Journal of Medical Science and Public Health, 4(12). https://doi.org/10.5455/ijmsph.2015.01042015338

Qu, B., Guo, H., Sun, G., Zuo, T., Zhang, Y., \& Brandon, Y. L. (2008) HIV/AIDS Knowledge, Attitudes, and Behaviors of Construction Workers in China.International Journal of Biomedical Science, 4(3), 192-195.

Tanzania Commission for AIDS (TACAIDS), Zanzibar AIDS Commission (ZAC), National Bureau of Statistics (NBS), Office of the Chief Government Statistician (OCGS), and ICF International. (2009). Tanzania HIV/AIDS and Malaria Indicator Survey 2007-08. Dar es Salaam, Tanzania: TACAIDS, ZAC, NBS, OCGS, and ICF International.

Tanzania Commission for AIDS (TACAIDS), Zanzibar AIDS Commission (ZAC), National Bureau of Statistics (NBS), Office of the Chief Government Statistician (OCGS), and ICF International. (2013). Tanzania HIV/AIDS and Malaria Indicator Survey 2011-12. Dar es Salaam, Tanzania: TACAIDS, ZAC, NBS, OCGS, 
and ICF International.

Tanzania HIV Fact Sheet. (2016). Retrieved 26th July, 2017 from https://www.usaid.gov/sites/default/files/documents/1860/Tanzania\%20HIV-AIDS\%20Fact\%20Sheet\%202 016.pdf

UNAIDS Fact Sheet. (2017). Retrieved 26th July, 2017 from http://www.unaids.org/sites/default/files/media_asset/UNAIDS_FactSheet_en.pdf

UNAIDS Fact Sheet. (2016). Retrieved 26th July, 2017 from http://www.unaids.org/sites/default/files/media_asset/UNAIDS_FactSheet_en.pdf

Weine, S. M., \& Kashuba, B. A. (2012). Labor migration and HIV risk: a systematic review of the literature. AIDS Behav., 16(6) 1605-1621. https://doi.org/10.1007/s10461-012-0183-4

Zhuang, X., Wu, Z., Poundstone, K., Yang, C., Zhong, Y., \& Jiang, S. (2012). HIV-Related High-Risk Behaviors among Chinese Migrant Construction Laborers in Nantong, Jiangsu. PLoS ONE, 7(3), e31986. https://doi.org/10.1371/journal.pone.0031986

\section{Copyrights}

Copyright for this article is retained by the author(s), with first publication rights granted to the journal.

This is an open-access article distributed under the terms and conditions of the Creative Commons Attribution license (http://creativecommons.org/licenses/by/4.0/). 